\title{
Analysis of the Effect of the Quality of Human Resources and Financial Management Information Systems on Village Financial Performance during the Covid 19 Pandemic
}

\author{
Meida Rachmawati ${ }^{1}$, Bambang Dewantoro ${ }^{2}$, Gatot Susilo ${ }^{3}$, Ari Pranaditya ${ }^{4}$, Sukardi $^{5}$ \\ Universitas Ngudi Waluyo, Ungaran ${ }^{1}$, AMIK JTC Semarang ${ }^{2}$, STMIK Bina Patria Magelang ${ }^{3}$, \\ Pandanaran University Semarang ${ }^{4}$, Universitas 17 Agustus Semarang ${ }^{5}$
}

\begin{abstract}
This review expects to investigate the impact of the nature of HR and monetary administration data frameworks on town monetary execution The research method used is exploratory research. Regarding the Quality of Human Resources and Financial Management Information Systems on Village Financial Performance during the Covid 19 Pandemic, financial management that has been carried out in the Semarang Regency Village is still manual, while the problems during the Coronavirus 19 pandemic are all activities related to Village Financial Performance encountered obstacles. Due to this, villages in Semarang district need to create a Financial Management information system that has Coronavirus 19 management features and financial transparency with the support of good quality human resources. The population in this study were villages in Semarang Regency with a total of 140 villages. Sampling with the purposive random sampling method. In this study, the population was relatively moderate, as many as 140 villages. The results obtained from the Quality of Human Resources and Information Systems decidedly affect the monetary presentation of villages in Semarang district, villagers can take advantage of the Financial Information System Easily, Practically, and Maintain Financial Performance Transparency without causing and always maintaining the residents' health protocol with Coronavirus management features.
\end{abstract}

Keywords: Quality of Human Resources; Financial Management Information System; Financial Performance

\section{Introduction}

Territorial advancement requires assets to drive the improvement exercises themselves, both those completed by the nearby government and the local area. The government as an actor who is the main driver of development will certainly manage its resources in the best way. Financial reports as a form of written information about local government finances in an accounting period, of course, must have accountability and transparency to realize good financial governance which is part of efforts to achieve good governance. As it is well-known that based on Government Regulation Number 71 of 2010, then a regional government financial report 
includes: (1) Budget realization report, (2) report on changes in excess budget balance (3) Balance sheet, (4) Operational Report (5) Cash flow report and (6) Equity change report (7) Notes to Financial Statements. The preparation of financial statements is directed to compiling on an accrual basis [1].

Human Resources is the main asset of development. Human resources in an organization are the drivers of activity, and without human resources, there will be no activities that can run to accomplish authoritative objectives. Human resources are also called labor or employees. Thus, the development of the workforce as human resources is a must so that the organization can continue to grow and compete in a competition with the organizational environment Manpower development is an effort to plan, improve capabilities, and manage them to develop high productivity [2]. In addition, human resources play a crucial role in an organization's efforts to reduce errors in calculations. Technology becomes something important in expediting and improving the quality of organizational activities. Management Information System Technology is now an integral part of administrative activities of improving the quality of activity reports. Similarly with local monetary administration where the local monetary administration data framework has been utilized in local monetary administration exercises [3].

The year 2020 is a year in which technological developments are increasingly advanced causes all human activities such as office work and so on to be made easier by the presence of digital technology today, which directly affects the efficiency of the work being done. The role of digital technology in assisting work in the private sector and public government, such as assisting in obtaining information quickly or recording information and tech can process data efficiently and sequentially to provide benefits for users of information technology, especially in the field of government bureaucracy [3]. Data processing needs to be carried out in every agency or organization where the data obtained is informative and can increase work productivity efficiency, time and cost. While on the one hand, the current situation where the world is facing the COVID-19 pandemic that causes all human activities to be hampered and affects the activities of one example in the bureaucracy related to villagers in Semarang Regency.

The Village Financial Management Information System is the main target to be developed. Villages in Semarang Regency still have not implemented a Village Information System where every work is related, especially to the Bureaucracy and Village Administration, for example, in the publication of financial data and data on the spread of Covid 19 infection is still done manually by village staff. It causes every work process and publication of financial data in improving village governance based on Good Governance which is related to accountability and openness in every implementation of Village Government in Semarang Regency [4]. The Village Financial Management Information System is applied using the Rapid Application Design method, which is a system development method that focuses on developing applications swiftly, through repetition and feedback from village staff, hamlet heads, village secretaries, and village heads [5].

\section{Theoretical Basis}

\section{Regional Financial Performance}

Execution is a consequence of work delivered by a representative that is defined to achieve the expected goals. In addition, performance can be interpreted as a interpretation of execution which implies crafted by a laborer, an administration cycle, or an association overall, where the 
consequences of the work should be shown substantial proof and can be estimated (contrasted with foreordained principles) [6]. Notoatmodjo (2015) suggests that performance is what a person can do following their duties and functions. Performance is an employee's performance which is the aftereffect of crafted by representatives both as far as quality and amount in doing and getting done with the jobs appointed to these workers by their bosses or pioneers dependent on their jobs in the organization. The organization should be viewed as representative execution as a significant component [7]. Employee performance will enormously affect the productivity of the company as a whole. The organization's efficiency will be low on the off chance that the worker's exhibition is low, as well as the other way around, the organization will be useful and develop assuming the representative's presentation is high. Worker execution will enormously influence the aftereffects of their work [8]. Village financial reform is arguably the greatest opportunity as well as a threat to the local government and DPRD to demonstrate the ability to explore and manage regional budgets without too much interference from the central government.

\section{Village Financial Management Information System}

\subsection{Principles of village financial management}

To help the acknowledgment of good administration in town organization, town monetary administration is completed dependent on administration standards, to be specific straightforward, responsible, and participatory, and did in a deliberate and monetary discipline. Town monetary administration is overseen inside a time of 1 (one) financial year, beginning from January 1 to December 31 [9].

\subsection{Transparancy}

In Article 4 section 7 of the Regulation of the Minister of Home Affairs of the Republic of Indonesia NO. 13 of 2006, concerning Guidelines for Regional Financial Management, it is said that straightforwardness is the standard of transparency that permits the general population to know and get the broadest conceivable admittance to data about local accounts. The presence of straightforwardness ensures access or opportunity for everybody to get data about the organization of government, in particular data about approaches, the most common way of making and carrying out them, just as the outcomes accomplished. Straightforwardness is the presence of an open approach for management. While what is implied by data is data about each part of government strategy that can be reached by the general population. Data exposure is relied upon to bring about solid, open minded political rivalry, and approaches are made dependent on open inclinations [10]. Straightforwardness is urgent for the execution of government works in doing the order of individuals. Considering that the public authority has the power to settle on different significant choices that influence many individuals, the public authority should give total data concerning what it is doing. With straightforwardness, lies are difficult to stow away. In this way straightforwardness turns into a significant instrument that can set aside individuals' cash from defilement.

The standards of straightforwardness can be estimated through a few markers as follows [11]: 1) Mechanisms that ensure the arrangement of transparency and normalization of all open help processes; 2) Mechanisms that work with public requests about different public approaches and administrations, just as cycles inside the public area; 3) Mechanisms that work with 
announcing and spread of data just as deviations from the activities of public authorities in serving exercises. The public authority's receptiveness to different parts of public administrations will at last make the public authority responsible to all partners with an interest in cycles and exercises in the public area.

\subsection{Acountability}

Responsibility is the commitment to give responsibility or reply and clarify the exhibition and activities of a lawful substance driving an association to parties who have the right or power to request data or responsibility. In executing responsibility inside government organizations, the accompanying standards should be thought of [12]:

a. There must be a commitment from the leadership and all agency staff to manage the implementation of the mission so that it is accountable;

b. It must be a system that can guarantee the use of resources consistent with the prevailing laws and regulations;

c. Must be able to show the level of achievement of the goals and objectives that have been set;

d. Must be oriented towards achieving the vision and mission as well as the results and benefits obtained;

e. Must be honest, objective, transparent, and innovative as a catalyst for change in the management of government agencies in the form of updating methods and techniques for measuring performance and preparing accountability reports (LAN \& BPKP, 2000).

\subsection{Partisipation}

While cooperation as per (LAN and BPKP, 2000) is that each resident has a voice in navigation, either straightforwardly or through the intermediation of authentic foundations that address their inclinations. The investment is assembled dependent on opportunity of affiliation and discourse just as useful interest. In Permendagri NO. 37 of 2007 concerning Village Financial Management, investment utilizes participatory, specifically dynamic local area support and association in the improvement cycle [9]. Local area investment in the assurance of public approaches is a main impetus to speed up the satisfaction of the responsibility guideline of government directors in the town. In planning, public investment is critical to forestall freak arrangements. Standards and signs of public cooperation in planning as indicated by Gatot Sulistioni, and Hendriadi (2004) incorporate the accompanying [12]: a) Access to dynamic public investment during the time spent program plan and financial plan direction; b) The presence of guidelines that give a position of control by autonomous establishments and the local area both independently and institutionally as a mechanism for governing rules. 3) There is a proactive disposition of the nearby government to empower resident cooperation in the planning system. It has given the sharp hole between open familiarity with how to take part adequately and the goals of acknowledging it.

The Village Financial Management Information System is a data innovation based local monetary administration framework that can help neighborhood legislatures in creating monetary data that is pertinent, quick, exact, complete, and can be confirmed. The data framework can likewise create monetary reports and other monetary data in a more exhaustive way which remembers data for the local monetary position, monetary execution conditions, and responsibility of nearby legislatures. The targets of utilizing the Financial Management Information System are [13]: 
a. Provide an integrated database of conditions in the region from the aspect of finance, regional assets, regional staffing/apparatus, and public services that can be used to assess the performance of local government agencies.

b. Produce comprehensive, precise, and accurate information to local government management. This information can be used as material for making decisions.

c. Prepare local officials to achieve a better level of mastery and utilization of information technology.

d. Strengthening the basis of local government in implementing regional autonomy.

\subsection{Quality of Human Resources (HR)}

Human resources play a crucial role both on a micro (organizational) and macro (country) scale. In every organization, big or small, international, regional or domestic, the major key to success for the organization lies in the quality of the human resources that control and run it. $\mathrm{HR}$ are the just assets that have sentiments, wants, abilities, information, consolation, power, and work (proportion, taste, and goal). Without the human element in the company, the company cannot move and walk towards what they want. HR needs to be managed properly and professionally to achieve a balance between HR needs and the demands and progress of the company's business. Werther \& Davis (1996) expressed that HR are representatives who are prepared, skilled, and alert in accomplishing hierarchical objectives. As expressed that the essential component of the asset side is its commitment to the association, while the essential element of a human is the treatment of its commitment, thusly, will decide the quality and capacity of life [14].

\section{Methodology}

This examination is remembered for expressive subjective exploration. As indicated by Sugiyono (2008), subjective exploration techniques are research strategies dependent on the way of thinking of postpositivism, used to inspect the state of normal items. Postpositivism reasoning is regularly alluded to as an interpretive and valuable worldview, which sees social reality as something all encompassing, intricate, dynamic, full of importance, and the relationship of manifestations is intelligent. In the interim, regular articles are objects that create as they are, not controlled by analysts, and the presence of specialists doesn't influence the elements of the item. This concentrate additionally attempts to depict the image of the peculiarities that happen in the execution of the Village Finance SIM application in the Semarang Regency Region.

In subjective exploration, the fundamental instrument as indicated by Sugiyono (2008), is simply the specialist, however at that point after the focal point of the examination ends up being undeniable, it is feasible to foster a straightforward examination instrument that is relied upon to finish the information and contrast it and the information that has been advanced through perception and meetings. Specialists go into the actual field, both in the fantastic visit question, centered and determination stage, gather information, break down and make ends.

The data collection technique used in this study was through field observation, the type of direct observation. The researcher conducting data collection stated frankly to the data source that he was conducting research. So, those who are being studied know from the beginning to the end about the activities of the researchers [15]. Observations of this research were carried out in Semarang Regency and all villages under the authority of Semarang Regency. 
The information assortment method is meeting. A meeting is a gathering of two individuals to trade data and thoughts through responsive so that significance can be built in a specific point [15]. The kind of meeting utilized in this review is a semi-organized meeting is remembered for the inside and out talk with class intended to find issues transparently, where the gatherings welcome to meet are requested their viewpoints. Interviews were directed by an open poll instrument. Meetings will be directed with the Village Head, Village Secretary, Village Treasurer, Village Consultative Body Representatives (BPD), overseers, administrators, and clients of Village finance SIMs to examine town monetary administration, assessment of Village monetary SIMs, and deterrents looked in carrying out Village monetary SIMs. Qualitative research analysis has started since formulating and explaining the problem before going into the field and continuing until the writing of research results [15]. An in-depth analysis has been carried out to explore all matters relating to the evaluation of the implementation of the Village Finance SIM application in the Semarang Regency.

\section{Results and Discussion}

Developing villages are villages that have adequate availability and access to primary services, infrastructure, accessibility or transportation, public services, and government administration.

In light of the consequences of perceptions and meetings, the Village Finance SIM application has been implemented since 2016 in Semarang Regency. This village financial SIM is better known as SISKEUDES (Village Financial System). Every year the Village financial SIM application changes are done to accommodate the development of financial transactions in the Village. The Village financial SIM is used to record all revenues obtained by the hamlet, including: Allocation of Village Funds (funds allocated by the district for villages sourced from central and regional balancing funds), Village Funds (sourced from APBD transferred through APBD and used to administer the government, village development, development, and community empowerment), Raksa Desa (sourced from the district government which is used for houses, nature, latrines, garbage, and water) and Provincial Assistance [16].

The Village financial SIM was developed by the Deputy for Supervision of Regional Financial Administration at the Central BPKP with the ability to produce output in the form of various administrative documents such as Proof of Receipt, SPP (Request for Payment), SSP (Tax Deposit Letter), budgeting reports (Perdes APB Desa, RAB, APB Desa per source of funds), and administrative reports (General Cash Book, Bank Book, Tax Book, Subsidiary Book, and Register) [17]. This application can organize the reporting flow of village government administration and monitor it centrally. The Village finance SIM application helps budget users minimize errors, both funds originating from the State Budget and Regional Revenue and Expenditure Budget.

In practice, the Village Treasurer in Semarang Regency has encountered difficulties when operating a Village financial SIM, among others: when there is a transaction that needs to be recorded, but there is no account code, the Girimekar Village Treasurer cannot automatically change it but must contact the DPMD (Department of Village Community Empowerment) to add a new account code, and difficulties when inputting nominal transactions that are subject to Article $22 \mathrm{PPh}$ tax and VAT, because sometimes invoices from suppliers include taxes and when inputted into the Village finance SIM application, the tax is recalculated, so that it can result in double imposition tax [17]. 
On the other hand, the Village Treasurer has difficulty operating the Village financial SIM application because it often has errors and cannot be accessed, and there are network problems. According to the Village Treasurer in Semarang Regency, in the operation of the Village Financial SIM application, there are several repeated orders, so it is necessary to input the same information several times. With the difficulties faced by the Village Treasurer of Semarang Regency, they need regular guidance and guidance from BPKP. This study indicates that the better the utilization of the Village Finance SIM, the stronger the quality of the budget in improving regional financial performance. It is following research conducted by Sudaryanti (2013) which revealed that the Regional Management Information System (SIMDA) is a means to assist regional financial management activities that includes budgeting, financial administration. The results of this study support research from Sudaryati that budgeting has a significant positive effect on performance through regional financial information systems [18].

\section{Conclusion}

The town has been given extraordinary trust to deal with its administration. The independence is expected to have an even dispersion of advancement execution to work on the government assistance and personal satisfaction of country networks so that issues like local inconsistencies, neediness, and socio-social issues can be limited. The Village Finance SIM is intended to support the accountability of village government administration, especially village budget management which must be transparent, accountable, participatory, and carried out in an orderly and budgetary discipline following Permendagri No. 113 of 2014.

The evaluation results of the Village Finance SIM in Cilengkarang District show that the Village Finance SIM has been implemented in the Village of Semarang Regency since 2016. The Village Finance SIM is used to record all activities funded from the Allocation of Village Funds, Village Funds, Village Funds, and Provincial Assistance. Constraints in implementing the Village Finance SIM are difficulties when operating the Village Finance SIM because: (1) there is often no account code, (2) the tax is imposed twice, (3) errors often occur and cannot be accessed, (4) there are network problems and (5) repetition of several commands.

Several recommendations were made to address this problem. The need for competent assistants in sufficient numbers assigned by the center with expertise in the fields of informatics, accounting, and management, so that technical problems can be resolved immediately. It is recommended that the Village Finance SIM application can be updated with an integrated system so that the process of inputting the same information only once and does not have to go through several stages. It will make it easier for the user to operate. The preparation of a manual for the operation of the Village Finance SIM and a manual for calculating taxes for both PPN, PPH 22, and Article 4 paragraph (2) needs to be done immediately. The application program should be updated because, so far, it is still using Visual Basic is very vulnerable to being hacked by parties who want to abuse the weaknesses inherent in Visual Basic. Training and socialization are needed every time the Village Finance SIM application version is updated. Tax training is also needed as a complement to avoid being taxed twice.

Based on the results of the research, the authors provide several suggestions, namely for each Regional Work Unit (SKPD) of Semarang Regency to improve the quality of human resources, with the most important and most decisive factor being the results achieved. With the experience of financial managers of regional work units (SKPD) getting better, it will reduce the error rate in completing work so that it will improve efficient financial performance. The Head of the Financial Management Section of the Semarang Regency Government improves 
regional financial performance by improving the quality of the budget, with the most important and most decisive factor being budget evaluation.

\section{References}

[1] Government Regulation Number 71 of 2010 Government Accounting Standards.

[2] Notoatmodjo, S. Pengembangan Sumber Daya Manusia. Rineka Cipta, Jakarta (2015).

[3] Budiman, F., \& Arza, F. I. Pendekatan Technology Acceptance Model Dalam Kesuksesan Implementasi Sistem Informasi Manajemen Daerah. (2013)

[4] Adisasmita, R. Pengelolaan Pendapatan dan Anggaran Daerah. Yogyakarta: Graha Ilmu. (2011).

[5] Government Regulation Number 58 of 2005 concerning Regional Financial Management.

[6] Hasibuan, M. S. Manajemen Sumber Daya Manusia. Jakarta: Bumi Aksara (2014).

[7] Arianty, N., Bahagia, R., Lubis, A. A., \& Siswadi, Y. Manajemen Sumber Daya Manusia. Medan: Perdana Publishing. (2016).

[8] Jufrizen, J. Efek Mediasi Kepuasan Kerja Pada Pengaruh Kompensasi Terhadap Kinerja Karyawan. Jurnal Ilmiah Manajemen Dan Bisnis, 17(1) (2016).

[9] Permendagri No. 37 Year 2007 concerning Government Accounting Standards.

[10] Bappenas and Depdagri. Buku Pedoman Penguatan Pengamanan Program Pembangunan Daerah. Kementerian Perencanaan Pembangunan Nasional, Jakarta (2002)

[11] Karina, P., and Loina Lalolo. Indikator dan Alat Ukur Prinsip Akuntabilitas, Transparansi, dan Partisipasi. Skretariat Good Public Governance Badan Perencanaan Pembangunan Nasional, Jakarta (2013)

[12] Sulistioni, Gatot, and Hendriadi. Prinsip dan Indikator Partisipasi Masyarakat. Bumi Aksara, Jakarta (2004)

[13] Halim, A. Manajemen Keuangan Sektor Publik. Jakarta: Salemba Empat. (2016)

[14] Werther, W. B., \& Davis, K. Human Resources and Personnel Management (5th ed.). Mc Graw Hill Companies Inc, New York (1996).

[15] Sugiyono. Education Research Method: Quantitatif, Qualitatif, and R\&D Approach. Alfabeta, Bandung (2008)

[16] Badan Pengawas Keuangan Dan Pembangunan. Modul Bimbingan Teknis Administrator System Require-ment SIMDA Keuangan Versi 2.1. Satuan Tugas Pengembangan SIMDA, Jakarta (2011)

[17] Al Athmay, Al. A. A., Fantazy, K., \& Kumar, V. E-government adoption and user's satisfaction: an empirical investigation. EuroMed Journal of Business, 11(1), pp. 57-83. https://doi.org/10.1108/EMJB-05-2014-0016 (2016)

[18] Sudaryati, D. Pengaruh Penganggaran Terhadap Kinerja Aparat Pemda Melalui Sistem Informasi Keuangan Daerah (Studi Kasus: Pemda Kab. Kudus). Jurnal Ekonomi Dan Bisnis, 12(1), pp. 11-24 (2013). 